\title{
Evaluation of Physical, Mechanical Properties and Pollutant Emissions of Wood-Magnesium Laminated Board (WML Board) for Interior Finishing Materials ${ }^{1}$
}

\author{
Hee-Jun $\mathrm{PARK}^{2,3} \cdot$ Seok-Un JO ${ }^{2,3, \dagger}$
}

\begin{abstract}
This study serves as basic research for the development of a new wood-based building finishing material that improved the weakness of inorganic materials such as gypsum board and magnesium board widely used as interior finishing materials and brought out the strength of the wood. The results of evaluating the physical and mechanical properties and the environmental effect related to hazardous substance discharge having manufactured a wood-magnesium laminated composite are as follows. The thermal conductivity and thermal resistance of WML board was improved by about 28 109 percent over magnesium board due to the low thermal conductivity of wood. The adhesive strength of WML board showed a similar result to that of plywood as it exceeds $0.7 \mathrm{~N} / \mathrm{mm}^{2}$, the adhesive standard of wood veneer which is presented by KS F 3101. Bending strength and screw holding strength were more improved by manufacturing WML board than magnesium board. The WML board manufactured in this study satisfied the criteria for emissions of hazardous substances prescribed in the Indoor Air Quality Control Act, and confirmed the possibility of development as a new wood-based composite material that can replace existing inorganic materials.
\end{abstract}

Keywords: wood-magnesium laminated board (WML Board), thermal resistance, interior finishing materials, total volatile organic compounds (TVOC), radon, toluene, formaldehyde

\section{INTRODUCTION}

The importance of safety and the environment in building materials for interior finishing is emphasized now more than ever, and Sick Building Syndrome (SBS), which adversely affects the health of occupants due to indoor air pollutants, is caused by building materials applied to indoor spaces. As a result, various measures are being sought to secure appropriate indoor air quality (Jang and Ryu, 2018).

In addition, due to a variety of advantages of wood to human beings and the environment, studies are being conducted around the world to replace parts of reinforced concrete structure, mineral materials, synthetic resins, and metal interior finishing materials with wood-based materials.

1 Date Received November 13, 2019, Date Accepted January 14, 2020

${ }^{2}$ Department of Housing Environmental Design, College of Human Ecology, Jeonbuk National University, Jeonbuk 54896, Republic of Korea

${ }^{3}$ Research Institute of Human Ecology, College of Human Ecology, Jeonbuk National University, Jeonbuk 54896, Republic of Korea

† Corresponding author: Seok-Un JO (e-mail: jo18041@naver.com, ORCID: 0000-0002-1271-0806) 


\section{Evaluation of Physical, Mechanical Properties and Pollutant Emissions of \\ Wood-Magnesium Laminated Board (WML Board) for Interior Finishing Materials}

Recently, with the global use of CLT as material for wooden building, studies on CLT are being conducted for fire safety, rationalization and improvement of manufacturing process, performance securing, and the like. Also similarly to this study, research is being conducted for the development of Ply-lam made by placing the mineral board, a refractory material, on the core layer, and plywood on the surface layer in the process of manufacturing CLT (Choi and Kang, 2018; Kim, et al., 2019).

It has been reported that bending strength and dimensional stability have been improved compared to conventional CLT by manufacturing an alternating lamination wood in which laminated board and plywood are arranged at the center of the CLT (Choi et al., 2015).

It has also been reported that if wood-magnesium laminated composite, which is the same as that in this study, is applied as an interior finishing material, the wood-magnesium laminated board is applied on the other side by moisture absorption and desorption chemicals after being drilled in order to improve the effect of indoor humidity control, and the measured amount of moisture absorption and desorption satisfies the green building material standard (average moisture absorption/desorption amount of $\left.65 \mathrm{~g} / \mathrm{m}^{2}\right)$ (Jo and Park, 2019a). Jang et al. (2017) analyzed HCHO and TVOC emissions and combustion characteristics of low-density fiberboard for building insulation and reported that low-density fiber boards manufactured from melamineurea-formaldehyde (MUF) were more suitable for building insulation. Wood is a combustible material which has caused enormous human life and property damage from fire, and in order to solve the problem of its limited application as a building material, woodmineral composites have been developed. And in order to secure fire retardant performance, a water-soluble phosphorus fire retardant is applied by $250 \mathrm{~g} / \mathrm{m}^{2}, 350 \mathrm{~g} /$ $\mathrm{m}^{2}, 450 \mathrm{~g} / \mathrm{m}^{2}$, and as a result of evaluating the fire retardant performance, it has been confirmed that all the specimens met the semi-noncombustible material criteria of Ministry of Land, Infrastructure and Transport (KS F ISO 5660-1:2015) and could be applied as a building material complying with fire safety standards (Jo and Park, 2019b). Lee et al.(2018) measured the radon concentration of five wood species (red pine, Japanese larch, hinoki cypress, sawtooth oak, northern red oak), and reported a radon concentration ranging from $0.00677\left[\mathrm{~Bq} /\left(\mathrm{m}^{2} \cdot \mathrm{h}\right)\right]$ to $0.01517\left[\mathrm{~Bq} /\left(\mathrm{m}^{2} \cdot \mathrm{h}\right)\right]$, which was negligible. As a safety precaution, it was suggested that infrastructure made of wood material should be designed in consideration of the inflow of radon, and also constructed accordingly.

This study provides basic research for the development of wood-magnesium laminated board (WML Board), which can preserve the advantages of wood and replace mineral materials (gypsum, vermiculite, magnesium, marble, tiles, etc.), synthetic resin products, and metallic building finishing materials that are widely used and improve indoor air quality, noise environment, fire safety, and seismic resistance. In this study, the main drawbacks of mineral building finishing materials, which include mechanical properties such as thermal properties, weak screw holding strength, and bending strength, as well as improvement of pollutant release and their applicability as an interior finishing material, have been reviewed.

\section{MATERIALS and METHODS}

\subsection{Testing materials}

\subsubsection{Wood veneer}

The wood veneer used to manufacture WML board is Pinus Radiata veneer of $1.6 \mathrm{~mm}$ thickness which is manufactured by a plywood production company in Incheon, Korea, with a specific gravity of 0.45 and moisture content of $12.79 \%$. 
Table 1. Basic properties of Magnesium board ${ }^{* 1}$ used In this study

\begin{tabular}{cccccccc}
\hline Items & $\begin{array}{c}\text { Thickness } \\
(\mathrm{mm})\end{array}$ & $\begin{array}{c}\text { Specific } \\
\text { Gravity }\end{array}$ & $\begin{array}{c}\text { Moisture } \\
\text { Content } \\
(\%)\end{array}$ & $\begin{array}{c}\text { Thermal } \\
\text { conductivity } \\
(\mathrm{W} /(\mathrm{m} \cdot \mathrm{K}))\end{array}$ & $\begin{array}{c}\text { Modulus of } \\
\text { Rupture } \\
\left(\mathrm{kg}_{\mathrm{f}} / \mathrm{cm}^{2}\right)\end{array}$ & $\begin{array}{c}\text { Screw } \\
\text { withdrawal } \\
\text { strength } \\
(\mathrm{kg} / \mathrm{mm})\end{array}$ & $\begin{array}{c}\text { Radon } \\
\text { concentration } \\
\left(\mathrm{Bq} / \mathrm{m}^{2} \cdot \mathrm{h}\right)\end{array}$ \\
\hline \hline $\begin{array}{c}\text { Magnesium } \\
\text { board }^{* 1}\end{array}$ & 3.0 & 0.90 & 13.04 & 0.109 & 183.55 & 2.04 & N.D. $^{* 2}$ \\
$($ MGO Board $)$ & & & & & & \\
\hline
\end{tabular}

${ }^{*}$ : Jiahui Mgo Board Technical Data from Jiahui Co.

${ }^{*}$ : Not detected

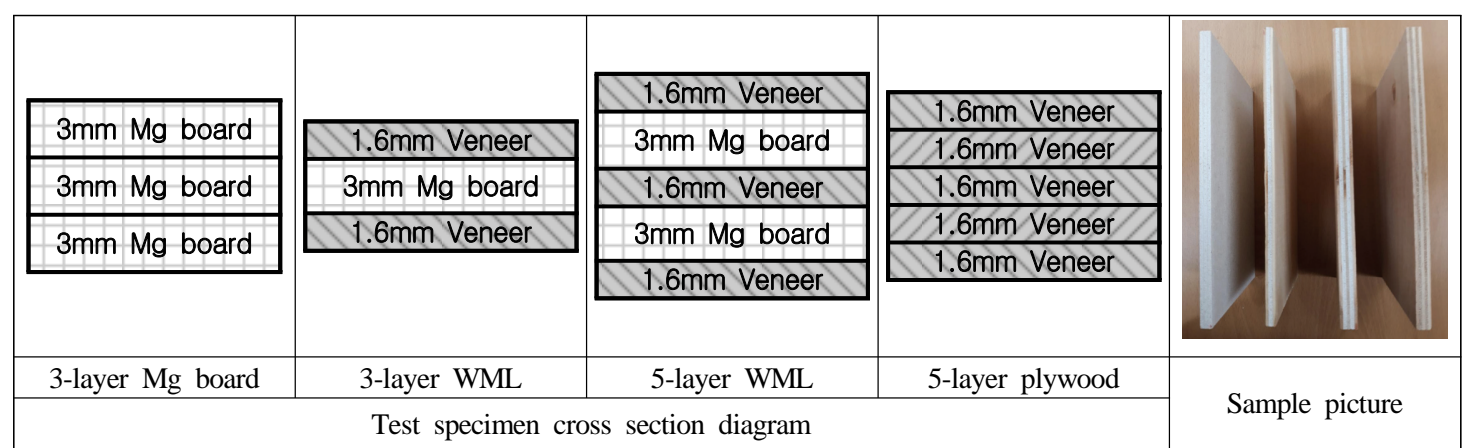

Fig. 1. Tested sample diagram and picture in this study (3-layer Mg board, 3-layer WML board, 5-layer WML board, 5-layer plywood from the left).

\subsubsection{Magnesium board}

Magnesium board (MGO board) used to manufacture the wood-magnesium laminated board is a product of the Chinese company Jiahui, whose basic material properties are presented in Table 1.

\subsection{Board manufacture}

In this study, in order to compare the properties of 5-layer plywood, 3- and 5-layer wood-magnesium laminated boards (3-layer WML board, 5-layer WML board) and 3-layer magnesium laminated boards (3-layer Mg board) were manufactured as shown in Fig. 1. The adhesive used to manufacture the boards was an a water-based EVA emulsion resin adhesive (ethylene-vinyl acetate copolymer (EVA) 40 50\%, Water $40 \sim 50 \%$, Etc. 10 20\%) with a viscosity of $700-800 \mathrm{cps} / 25^{\circ} \mathrm{C}$ and a solid content of $58-61 \%$ manu- factured by a company in Korea, with spreading amounts of $200 \mathrm{~g} / \mathrm{m}^{2}$, pressure of $7 \mathrm{~kg}_{\mathrm{f}} / \mathrm{cm}^{2}$ and cold press of 12 hours. The boards are produced at $300 \mathrm{~mm} \times 600 \mathrm{~mm}$, and the cross-section diagram and picture of the manufactured boards is as seen in Fig. 1.

\subsection{Testing method}

In this study, 5-layer plywood, 3-layer WML board, 5-layer WML board, and 3-layer Mg board were manufactured according to Section 2.2 above, and the physical and mechanical properties of each material were compared and evaluated, while the environmental suitability for application as an interior building finishing material was evaluated in accordance with the Indoor Air Quality Control Act (Ministry of Environment, 2018). 
Evaluation of Physical, Mechanical Properties and Pollutant Emissions of

Wood-Magnesium Laminated Board (WML Board) for Interior Finishing Materials

\subsubsection{Physical properties}

For the physical properties of the manufactured boards, specific gravity, moisture content, thermal conductivity and thermal resistance were measured. The specific gravity and moisture content were measured according to KS F 3104:2016 (Particleboard) and the thermal conductivity and thermal resistance were measured and compared according to KS L 9016:2010 (Test methods for thermal transmission properties of thermal insulation) and KS M ISO 6946:2013 (Building components and building elements-Thermal resistance and thermal transmittance-Calculation method).

\subsubsection{Mechanical properties}

For the mechanical properties of the manufactured boards, bending strength and screw holding strength were measured according to KS F 3104:2016 (Particleboard). In addition, for the adhesion between wood veneer and magnesium board, Dry bonding strength (shear adhesion) and water resistant shear adhesion (Type 2) were measured according to KS F 3101:2016 (Ordinary plywood).

\subsubsection{Pollutant emissions}

In order to review the applicability of WML boards developed in this study as interior finishing materials, it has been committed to Korea Conformity Laboratories (KCL) to measure the emission amounts of total volatile organic compounds (TVOC), toluene, and formaldehyde (HCHO). Also, the concentration of radon (Rn-22), which has been a controversial mineral material recently, was compared with the emission standard suggested by relevant laws (Ministry of Environment, 2018).

\section{RESULTS and DISCUSSION}

\subsection{Physical properties}

The measurement results for physical and mechanical properties and environmental evaluation of the manufactured boards are shown in Table 2. The results of measuring the thermal conductivity and thermal resistance of each board manufactured in this study are shown in Table 2, Fig. 2 and Fig. 3. While the thermal conductivity of 5-layer plywood made by laminating 5 wood veneers was $0.099(\mathrm{~W} / \mathrm{m} \cdot \mathrm{K})$, that of 3-layer $\mathrm{Mg}$ board made by laminating 3 magnesium boards was 0.250 , which is about 2.53 times higher than laminated wood veneers. The thermal conductivities of 3-layer WML and 5-layer WML which are manufactured by laminating $1.6 \mathrm{~mm}$ thick wood veneers

Table 2. Physical, Mechanical Properties and Pollutant emissions of tested specimens

\begin{tabular}{|c|c|c|c|c|c|c|c|c|c|c|c|c|}
\hline \multirow[b]{2}{*}{ Material } & \multirow[b]{2}{*}{ Sp.Gr. ${ }^{* 1}$} & \multirow{2}{*}{$\begin{array}{l}\mathrm{MC}^{* 2} \\
(\%)\end{array}$} & \multirow{2}{*}{$\begin{array}{c}\text { Thermal } \\
\text { transmission } \\
(\mathrm{W} /(\mathrm{m} \cdot \mathrm{K}))\end{array}$} & \multirow{2}{*}{$\begin{array}{l}\text { Thermal } \\
\text { insulation } \\
\left(\mathrm{m}^{2} \cdot \mathrm{K} / \mathrm{W}\right)\end{array}$} & \multicolumn{2}{|c|}{$\begin{array}{l}\text { Adhesion } \\
\left(\mathrm{N} / \mathrm{mm}^{2}\right)\end{array}$} & \multirow{2}{*}{$\begin{array}{l}\text { Modulus } \\
\text { of } \\
\text { Rupture } \\
\text { (Mpa) }\end{array}$} & \multirow{2}{*}{$\begin{array}{c}\text { Screw } \\
\text { withdrawal } \\
\text { strength } \\
\text { (N) }\end{array}$} & \multirow{2}{*}{$\begin{array}{c}\mathrm{HCHO} \\
\left(\mathrm{mg} / \mathrm{m}^{2} \cdot \mathrm{h}\right)\end{array}$} & \multirow{2}{*}{$\begin{array}{l}\text { Toluene } \\
\left(\mathrm{mg} / \mathrm{m}^{2} \cdot \mathrm{h}\right)\end{array}$} & \multirow{2}{*}{$\begin{array}{c}\text { TVOC } \\
\left(\mathrm{mg} / \mathrm{m}^{2} \cdot \mathrm{h}\right)\end{array}$} & \multirow{2}{*}{$\begin{array}{l}\mathrm{Rn}-222 \\
\left(\mathrm{~Bq} / \mathrm{m}^{3}\right)\end{array}$} \\
\hline & & & & & $\begin{array}{c}\text { Dry } \\
\text { bonding } \\
\text { shear }\end{array}$ & $\begin{array}{c}\text { Water } \\
\text { resistant } \\
\text { shear }\end{array}$ & & & & & & \\
\hline $\begin{array}{l}\text { 3-layer } \\
\text { Mg board }\end{array}$ & 1.17 & 13.13 & 0.25 & 36.00 & - & - & 20.07 & 653.29 & - & - & - & - \\
\hline $\begin{array}{c}\text { 3-layer } \\
\text { WML board }\end{array}$ & 0.82 & 12.75 & 0.13 & 46.27 & $0.99 \pm 0.26$ & $0.76 \pm 0.17$ & 43.43 & 752.44 & N.D. ${ }^{* 4}$ & N.D. ${ }^{* 4}$ & 0.150 & $12.9^{* 3}$ \\
\hline $\begin{array}{c}\text { 5-layer } \\
\text { WML board }\end{array}$ & 0.77 & 12.16 & 0.14 & 75.52 & - & - & 32.02 & 868.87 & - & - & - & - \\
\hline $\begin{array}{l}\text { 5-layer } \\
\text { Plywood }\end{array}$ & 0.45 & 12.79 & 0.09 & 80.81 & - & - & 49.57 & 895.82 & - & - & - & - \\
\hline
\end{tabular}

${ }^{* 1}$ : Specific gravity, ${ }^{* 2}$ : Moisture content, ${ }^{* 3}$ : Radon concentration per unit volume,

${ }^{*}$ : Not detected 


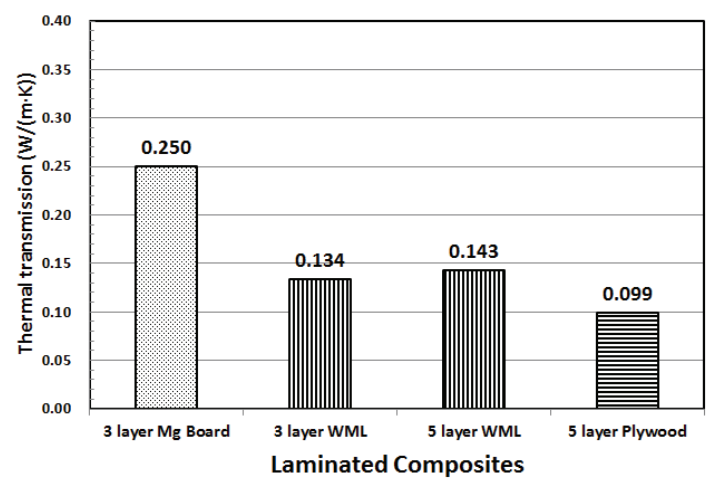

Fig. 2. Thermal transmission of laminated composites.

on $3 \mathrm{~mm}$ thick magnesium board were about $46 \%$ and $43 \%$ lower respectively than those of magnesium board. Cemal et al. (2019) analyzed the correlation between thermal conductivity and density of wood and bending strength, and reported that the thermal conductivity of Scots pine and Sessile oak was $0.133(\mathrm{~W} / \mathrm{m} \cdot \mathrm{K})$ and $0.160(\mathrm{~W} / \mathrm{m} \cdot \mathrm{K})$, respectively. This showed that the thermal conductivity of solid wood is higher than the 5-layer plywood and lower than the 3-layer Mg board of this study.

Thermal resistance was $80.808\left(\mathrm{~m}^{2} \cdot \mathrm{K} / \mathrm{W}\right)$, the highest in 5-layer plywood, $75.52\left(\mathrm{~m}^{2} \cdot \mathrm{K} / \mathrm{W}\right)$ in 5-layer WML, $46.27\left(\mathrm{~m}^{2} \cdot \mathrm{K} / \mathrm{W}\right)$ in 3-layer WML, and $36.00\left(\mathrm{~m}^{2} \cdot \mathrm{K} / \mathrm{W}\right)$ in 3-layer $\mathrm{Mg}$ board as shown in Fig. 3. With these results, it was shown that by laminating 2 or 3 wood veneers of $1.6 \mathrm{~mm}$ thickness on a magnesium board to make 3-layer WML and 5-layer WML, their thermal resistances can be increased by $28.8 \%$ from 36.00 $\left(\mathrm{m}^{2} \cdot \mathrm{K} / \mathrm{W}\right)$ to $46.27\left(\mathrm{~m}^{2} \cdot \mathrm{K} / \mathrm{W}\right)$, and by $109.8 \%$ from 36.00 $\left(\mathrm{m}^{2} \cdot \mathrm{K} / \mathrm{W}\right)$ to $75.52\left(\mathrm{~m}^{2} \cdot \mathrm{K} / \mathrm{W}\right)$, respectively. Therefore, it is expected that with the manufacture of woodmagnesium laminated composite in which wood veneers are laminated on the surfaces of mineral materials such as magnesium boards and gypsum boards widely used as interior finishing materials, the natural advantages of wood can be strengthened and the thermal resistance can be elevated, which can contribute to energy saving

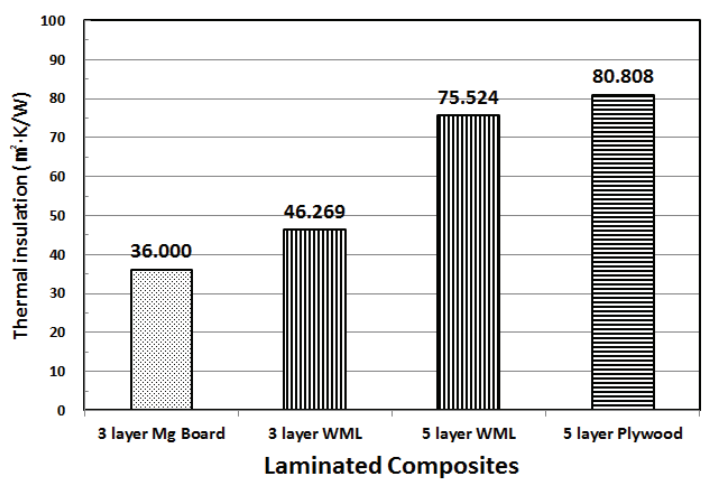

Fig. 3. Thermal insulation of laminated composites.

with an improvement of the insulation effect.

\subsection{Mechanical properties}

The results of measuring the dry bonding strength (shear adhesion) and water resistant shear adhesion (Type 2) between wood veneer and magnesium board, bending strength, and surface screw withdrawal strength, which is used to manufacture four kinds of boards in this study, are shown in Table 2, Fig. 4, Fig. 5, and Fig. 5 respectively.

The adhesion between the materials refers to the adhesion between disparate materials among four kinds of boards, which evaluated the possibility of manufacturing wood-magnesium board by measuring the

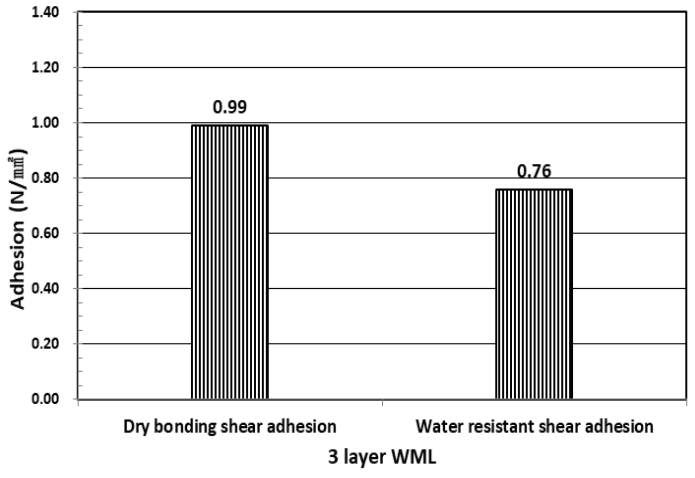

Fig. 4. Adhesion of 3-layer WML Board. 
Evaluation of Physical, Mechanical Properties and Pollutant Emissions of

Wood-Magnesium Laminated Board (WML Board) for Interior Finishing Materials

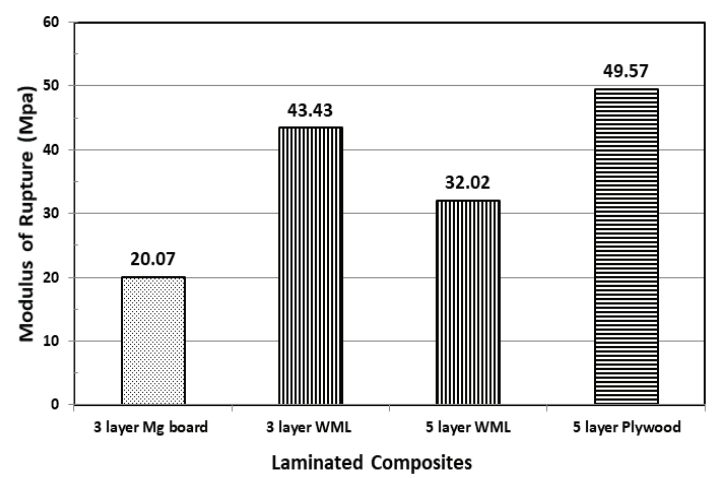

Fig. 5. Bending strength(MOR) of laminated composites.

adhesion of wood veneer and mineral materials (magnesium board) which are considered to have the weakest adhesion. As shown in Table 2 and Fig. 4, the adhesion measured in accordance with the KS F 3101(Ordinary Plywood) standards of the EVA emulsion resin adhesive, used on laminated wood veneer and magnesium board, were $0.99 \mathrm{~N} / \mathrm{mm}^{2}$ in dry bonding shear adhesion and $0.76 \mathrm{~N} / \mathrm{mm}^{2}$ in water resistant shear adhesion respectively. These are the values which exceed 0.7 $\mathrm{N} / \mathrm{mm}^{2}$, the adhesion standard of wood veneer suggested by KS F 3101, and the delamination phenomenon in the adhesive layer could not be confirmed even when the bending load was imposed during the bending strength test. Therefore, it is acknowledged that even when manufacturing a board by laminating wood veneers and magnesium boards with the room temperature curing EVA emulsion resin adhesive which is applied in this study, a good adhesive force equaling that between wood veneers suggested by KS can be secured.

The results of measuring the bending strengths of the four kinds of boards which are manufactured in this study are as shown in Table 2 and Fig. 5. The bending strength of boards measured in accordance with “KS F 3104 (Particleboard)” were the highest value in 5-layer plywood (49.57MPa) and lowest in 3-layer Mg board (20.07 MPa), 43.43 MPa in 3-layer WML,

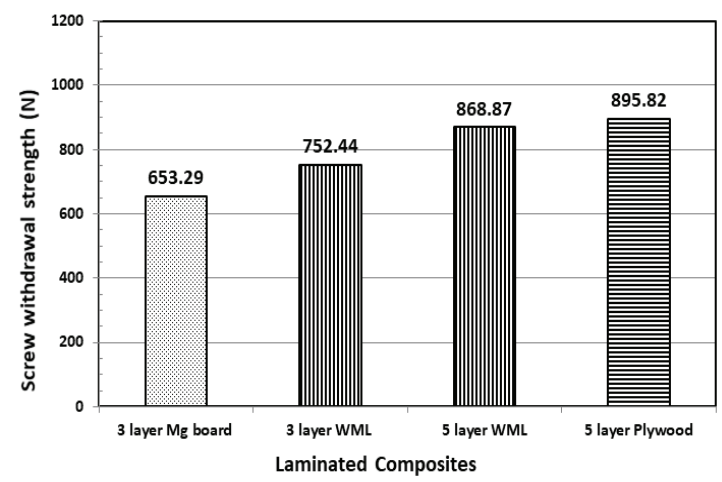

Fig. 6. Screw withdrawal strength of laminated composites.

and 32.02 MPa in 5-layer WML as shown in Fig. 5. With these results, it was shown that by laminating 2 or 3 wood veneers of $1.6 \mathrm{~mm}$ thickness on a magnesium board to make 3-layer WML and 5-layer WML, their bending strength can be increased by $116.4 \%$ from 20.07 MPa to $43.43 \mathrm{MPa}$, and by $59.5 \%$ from 20.07 MPa to 32.02 $\mathrm{MPa}$, respectively.

Therefore, it is expected that with the manufacture of WML in which wood veneers are laminated on the surfaces of magnesium boards, the bending strength can be elevated, which can improve the durability of mineral type materials.

The plane screw withdrawal strengths of the four types of boards made in this study are as shown in Table 2 and Fig. 6. As shown in the table and figure, they were $895.82 \mathrm{~N}$, the highest in 5-layer plywood, and $653.29 \mathrm{~N}$, the lowest in 3-layer Mg board. In the wood-magnesium laminated composite, 3-layer WML and 5-layer WML plane screw withdrawal strengths were $752.44 \mathrm{~N}$ and $868.87 \mathrm{~N}$ respectively in woodmagnesium laminated composites, showing that the screw withdrawal strength is stronger than that of 3-layer $\mathrm{Mg}$ board, and that of 5-layer WML is closer to that of 5-layer plywood. The screw withdrawal strength is an importance factor to prevent interior finishing materials from falling or being damaged due to earthquakes or impacts especially when they are applied 


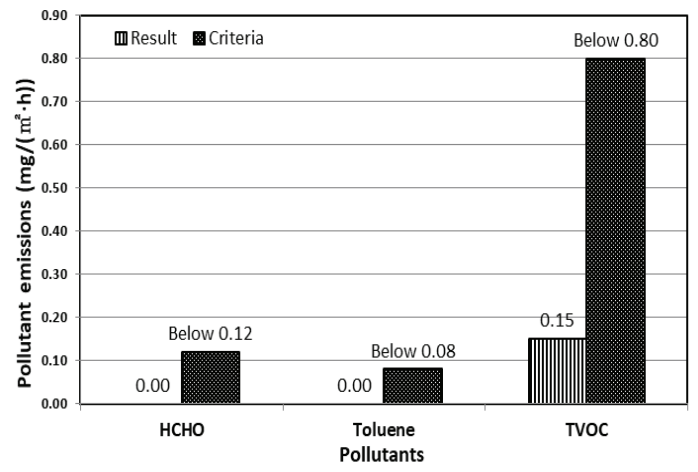

Fig. 7. Pollutant emissions of 3-layer WML.

to walls or ceilings, shown in cases when finishing materials such as gypsum boards, tiles and bricks of ceilings or walls fell or were damaged during the earthquake in Pohang in 2017 and in Gyeongju in 2016. The wood-magnesium laminated composite manufactured in this study was proved to exceed $700 \mathrm{~N} / 15 \mathrm{~mm}$, the standard for plane screw withdrawal strength of 18 type particleboard suggested by "KS F 3104, Particleboard”, and was able to improve on a weak screw withdrawal strength, one of the weaknesses that mineral materials have by about 15 to 33\% with WML boards.

\subsection{Pollutant emissions}

Hazardous substances generated from building finishing materials are known to be a factor with a harmful effect on human beings and the environment, and the Korean government also enforces the "Enforcement rules of the Indoor Air Quality Control Act” [Attachment 3], [Attachment 5], (Ministry of Environment, 2018). Main hazardous substances include formaldehyde, tol- uene, total volatile organic compounds and radon concentration, and these substances are known to stem mainly from mineral materials and adhesives. In this study, emissions and concentrations of 3-layer WML in which magnesium board and wood veneers are glued together have been measured by the Korea Conformity Laboratories (KCL).

According to the "Enforcement rules of the Indoor Air Quality Control Act” [Attachment 5] (Ministry of Environment, 2018), wood based panel products should contain less than $0.12 \mathrm{mg} /\left(\mathrm{m}^{2} \cdot \mathrm{h}\right)$ of formaldehyde, 0.08 $\mathrm{mg} /\left(\mathrm{m}^{2} \cdot \mathrm{h}\right)$ of toluene, and $0.8 \mathrm{mg} /\left(\mathrm{m}^{2} \cdot \mathrm{h}\right)$ of total volatile organic compounds.

The pollutant emissions of 3-layer WML board made in this study are as shown in Table 2 and Fig. 7.

AS a result of measuring the WML boards developed in this study, formaldehyde and toluene were not detected and total volatile organic compounds (TVOC) was shown at $0.150 \mathrm{mg} / \mathrm{m}^{2} \cdot \mathrm{h}$, complying with the standard provided by the Environment display authentication criteria (EL248:2016). In addition, since the recommended standards for radon concentration provided are under $148 \mathrm{~Bq} / \mathrm{m}^{3}$ by the "Enforcement rules of the Indoor Air Quality Control Act” (Ministry of Environment, 2018), the maximum radon concentration of the WML manufactured in this study was $21.3 \mathrm{~Bq} / \mathrm{m}^{3}$ and 7-day average radon concentration was $12.9 \mathrm{~Bq} / \mathrm{m}^{3}$, about $8.7 \%$ of the standard, showing that there are no problems in applying it as an interior finishing material.

The following Fig. 8 shows examples of WML board prototypes developed in this study.

Table 3. Test results of Radon (Rn-222) concentration of WML board

\begin{tabular}{ccccc}
\hline Items & $\begin{array}{c}\text { Max. Rn } \\
\text { concentration } \\
\left(\mathrm{Bq} / \mathrm{m}^{3}\right)\end{array}$ & $\begin{array}{c}\text { Avg. Rn concentration } \\
\text { for 7days } \\
\left(\mathrm{Bq} / \mathrm{m}^{3}\right)\end{array}$ & $\begin{array}{c}\text { Radon concentration per Radon concentration per } \\
\text { unit mass } \\
(\mathrm{Bq} /(\mathrm{kg} \cdot \mathrm{h}))\end{array}$ & $\begin{array}{c}\text { unit } \\
\left(\mathrm{Bq} /\left(\mathrm{m}^{2} \cdot \mathrm{h}\right)\right)\end{array}$ \\
\hline \hline $\begin{array}{c}\text { 3-layer WML } \\
\text { Criterion }\end{array}$ & 21.3 & 12.9 & 0.008 & 0.019 \\
\hline
\end{tabular}


Evaluation of Physical, Mechanical Properties and Pollutant Emissions of Wood-Magnesium Laminated Board (WML Board) for Interior Finishing Materials

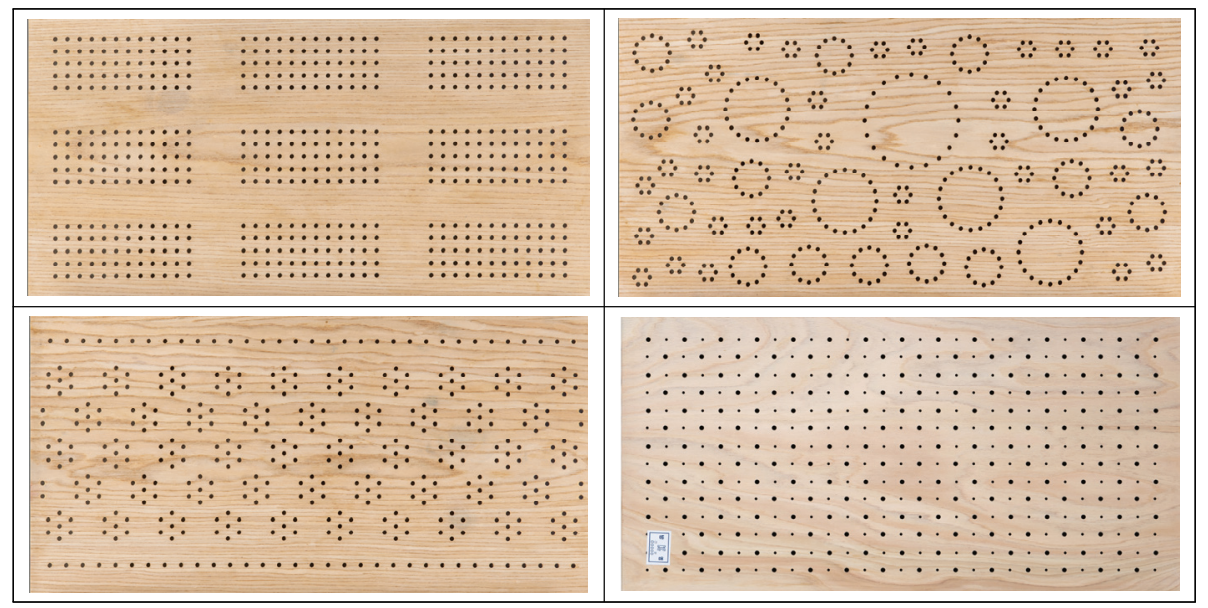

Fig. 8. Examples of WML board prototypes.

\section{CONCLUSION}

This study provides basic research for the development of a new wood-based building finishing material that improved the weakness of inorganic materials such as gypsum board and magnesium board widely used as interior finishing materials and brought out the strength of the wood. The results of evaluating the physical and mechanical properties and the environmental effect related to hazardous substance discharge from wood-magnesium laminated composite manufacturing are as follows.

(1) It turned out that it is possible to lighten the weight of magnesium by laminating wood veneer and magnesium board in 3 layers or 5 layers and to improve the thermal conductivity and thermal resistance of magnesium board by about $28 \%$ to $109 \%$ as a building finishing material due to the low thermal conductivity of wood.

(2) Though wood veneer and magnesium are disparate materials, the adhesive strength between them has shown a similar result to that of plywood as it exceeds $0.7 \mathrm{~N} / \mathrm{mm}^{2}$, the adhesive standard of wood veneer which is presented by KS F 3101.
It is also judged that there will be no problem in applying it as an interior finishing material.

(3) It appeared that the mechanical performance such as bending strength and screw retention force can be better improved by manufacturing woodmagnesium laminated composite than that of magnesium boards. In particular, the improved screw retention force is expected to contribute greatly to the prevention of finishing materials from falling and damage from earthquakes or impacts when constructed as wall or ceiling materials.

(4) The wood-magnesium laminated composite manufactured in this study has satisfied the criteria for emission of hazardous substances prescribed in the Indoor Air Quality Control Act, and confirmed the possibility of development as a new wood-based composite material that can replace existing inorganic materials.

\section{ACKNOWLEDGMENT}

This study was carried out with the support of 'R\&D Program for Forest Science Technology (Project 
No. FTIS2018116A00-1920-AB01)’ provided by Korea Forest Service (Korea Forestry Promotion Institute).

\section{REFERENCES}

Cemal, Ö, Mustafa, K. 2019. Determination of relationship between thermal and mecanical properties of wood material. Journal of the Korean Wood Science and Technology 47(4): 408-417.

Choi, C., Yuk, C.R., Yoo, J.C., Park, J.Y., Lee, C.G., Kang, S.G. 2015. Physical and mechanical properties of cross laminated timber using plywood as core layer. Journal of the Korean Wood Science and Technology 43(1): 86-95.

Choi, G.W., Kang, S.G. 2018. Improvement and rationalization of manu fac turing processing of plywood core CLT. 2018 Proceedings of the Korean society of wood sci. and tech. annual meeting, p.81.

Jang, K.Y., Ryu, D.W. 2018. Performance evaluation of water vapor adsor ption \& desorption properties of ceramic panel and painting materials for humidity control. Journal of the Architectural Institute of Korea Structure \& Construction 34(3): 43-52.

Jang, J.H., Lee. M., Kang, E.C., Lee, S.M. 2017. Characteristics of Low Density Fiberboards Bonded with Different Adhesives for Thermal Insulation (II)-Formaldehyde-Total Volatile Organic Compounds Emission Properties and Combustion Shapes-. Journal of the Korean Wood Science and Technology 45(5): 580-587.

Jo, S.U., Park, H.J. 2019. Absorption and desorption of moisture performance of wood-magnesium laminated composite treated with absorption and desorption chemicals. 2019 Proceedings of the
Korean Society of Wood Science and Technology. fall meeting, p.24.

Jo, S.U., Park, H.J. 2019. Flame retardant performance of wood-magnesium laminated composite treated with flame retardant chemicals. 2019. Proceedings of the Korean Society of Wood Science and Technology annual meeting, p.67.

Kim, K.J., Yang, S.M., Kang, S.G. 2019. A study on the Fire Resistance of Inorganic board mixed Ply-lam. 2019 Proceedings of the Korean society of wood sci. and tech. fall meeting, p.29.

Korea Standard Association: Building components and building elements-Thermal resistance and thermal transmittance Calculation method, KS M ISO 6946, 2013.

Korea Standard Association: Ordinary Plywood, KS F 3101, 2016.

Korea Standard Association: Particleboard, KS F 3104, 2016.

Korea Standard Association: Test Methods for thermal transmission properties of thermal insulations, KS L 9016, 2017.

Lee, J.Y., Choi, G.W., Kang, S.G. 2018. Radon exhalation from five wood species, Journal of the Korean Wood Science and Technology 46(6): 735-747.

Ministry of Environment, 2018. Enforcement rules of the Indoor Air Quality Control Act.

Park, H.J., Jo, S.U., Kang, C.W. 2019. Physical and mechanical properties of wood-magnesium laminated composite (WM Board). Proceedings of the Korean sSociety of Wood Science and Technology annual meeting, p.40. 